\title{
PENGARUH PEMBERIAN BERBAGAI TINGKAT CHASEY NUT SHELL LIQUID (CNSL) TERHADAP MORTALITAS Tribolium castaneum PADA DEDAK PADI
}

\author{
(The Effect Of Various Levels Of Nut Shell Liquid (CNSL) On The Mortality Of \\ Tribolium castaneum In Rice Bran)
}

\author{
Ramadika, Ana R. Tarmidi, Iman Hernaman \\ Departemen Nutrisi Ternak dan Teknologi Pakan, Fakultas Peternakan Universitas Padjadjaran, \\ Jalan Raya Bandung - Sumedang Km. 21, Jatinangor, Sumedang, 45363 \\ e-mails : iman.hernaman@unpad.ac.id
}

Article Submitted : 30-06-2019

Article Accepted : 31-08-2019

\begin{abstract}
This study aims to determine the effect of various levels of chasey nut shell liquid (CNSL) on the mortality of Tribolium castaneum in rice bran. The study was conducted experimentally using a completely randomized design (CRD) with five types of concentration treatments given CNSL, namely $\mathrm{R} 0=0 \%, \mathrm{R} 1=10 \%, \mathrm{R} 2=10 \%, \mathrm{R} 3=20 \%, \mathrm{R} 4=30 \%$, R5, $=$ $40 \%$. Each treatment was repeated four times. The results showed that the concentration of CNSL gave a significant effect $(\mathrm{P}<0.05)$ on mortality of Tribolium castaneum and shrinkage of rice bran, with a concentration of $40 \%$ resulting in the highest mortality. The relationship between the number of Tribolium castaneum and rice bran shrinkage formed a regression equation $\mathrm{Y}=0.0013 \mathrm{X}+0.1695$ with a value of $\mathrm{R}^{2}=0.5701$, while the number of Tribolium castaneum and rice bran shrinkage was closely related to the value $\mathrm{r}=0.76$. Conclusion, the use of CNSL causes mortality in the Tribolium castaneum
\end{abstract}

Keywords : chasey nut shell liquid, mortality, rice bran, Tribolium castaneum

\section{PENDAHULUAN}

Dedak padi merupakan hasil sampingan proses penggilingan padi yang terdiri atas lapisan luar (kulit ari) butiran padi dengan sejumlah lembaga biji. Bahan pakan ini mempunyai potensi yang besar sebagai sumber energi bagi ternak, yang dicirikan dengan rendahnya kandungan protein $(8-10 \%)$ serta tingginya kandungan seratnya (15\%). Biasanya setelah diproduksi dedak padi tidak langsung digunakan, namun dikumpulkan dan disimpan terlebih dahulu sampai jumlahnya mencukupi dan lalu dijual ke pabrik pakan atau ke konsumen. Penggunaannya juga tidak langsung habis pada saat itu dan disimpan di gudang untuk beberapa hari bahkan beberapa minggu kemudian. Pada saat penyimpanan dedak padi rawan terhadap gangguan serangga diantaranya kehadiran kumbang jenis Tribolium castaneum. Cypra (2001) menyatakan bahwa kumbang ini merupakan hama penganggu.

Tribolium castaneum dalam pakan dapat menurunkan kualitas dan menyebabkan penurunanan bobot karena memakan komponen pati. Pengamatan dedak padi yang terinfeksi kumbang di bawah pewarnaan tetrazolium menunjukkan adanya tingkat kerusakan (Freeman, 1995). Disamping itu, sekresinya bersifat toksik yang menyebabkan gangguan pencernaan pada ternak (Marthin, 2001). Adanya jasad mati dari Tribolium castaneum akan menrunkan kualitas dari serelia secara fisik maupun secara kimiawi. 
Perlakuan dengan menggunakan zat kimia telah diterapkan secara luas di beberapa industri pakan di Indonesia, namun demikian hal tersebut tidak menunjukkan pengaruh yang besar terhadap mortalitas Tribolium castaneum (Freeman, 1995). Dengan fumigasi masal menggunakan kimia sebanyak 2 kali dalam seminggu tingkat mortalitas Tribolium castaneum hanya 15$20 \%$. Artinya dengan fumigasi menggunakan insektisida kimia sintetik ternyata masih ditemukan Tribolium castaneum dalam jumlah cukup besar. Di lain pihak, penggunaan bahan kimia beresiko menganggu kesehatan ternak maupun manusia.

Pada pengolahan biji jambu mete menghasilkan limbah padat berupa kulit biji mete sebanyak $67 \%$ dari mete glondong. Kulit biji mete mengandung 32-37\% minyak kuning yang disebut laka atau CNSL (Cashew Nut Shell Liquid). CNSL mengandung senyawa fenol alam terdiri atas asam anakardat kardol.2-metil kardol dan kardanol (Tyman, 1975) yang berperan dalam bidang industri, juga mempunyai sifat anti bakteri (Himejima, 1991) dan dapat digunakan sebagai agen fumigasi nabati (Murthy and Sivasamban, 1984). Penggunaan CNSL dengan konsentrasi 25\% dengan metode semprot dalam tanaman industri pada ruangan terbuka dapat menghasilkan tingkat mortalitas Helopeltis antonii Sign sebesar 40\% (Warsi dan Tri, 2004).

\section{METODE PENELITIAN}

Dedak disaring dengan saringan Restch pada semua level saringan agar terbebas dari kontaminan atau partikel non dedak serta tidak menyulitkan perhitungan Tribolium castaneum, kemudian difumigasi dengan fumigant kimia merk Erol-43 sebanyak $5 \mathrm{~mL}$ dengan konsentrasi $15 \%$. Fumigasi dilakukan dengan tujuan untuk memastikan bahwa tidak terdapat kontaminasi Tribolium castaneum pada dedak padi pra penelitian. Setelah itu ditutup kain kasa bukaan saringan 9,95 $\mathrm{mm}$, kemudian dijemur di bawah sinar matahasi selama 5 jam untuk menguapkan fumigan sehingga pada saat penelitian tidak ada kontaminasi fumigan pada dedak padi. Seluruh peralatan yang digunakan dibersihkan dengan desinfektan. Berikutnya dedak padi dimasukan dalam botol selai (kapasitas 300 g) sebanyak 250 g tiap sampelnya.

Larutan CNSL disiapkan dengan konsentrasi sesuai perlakuan, yaitu $0 \%$ (R0), 10\% (R1), 20\% (R2), 30\% (R3), dan 40\% (R4) yang dimasukan ke dalam botol spray. Setelah itu disemprotkan secara perlahanlahan sebanyak $5 \mathrm{~mL}$ pada tiap sampel dedak padi sambil diaduk menggunakan batang pengaduk dengan pola adukan membentuk angka 8. Kemudian ke dalam botol selai yang berisi dedak padi tersebut diinokulasi Tribolium castaneum sebanyak 50 ekor tiap sampelnya. Lalu botol selai ditutup dengan potongan busa. Untuk menghitung jumlah Tribolium castaneum digunakan kaca pembesar (Lup). Sampel tersebut disimpan selama 21 hari.

Setelah penyimpanan selama 21 hari dilakukan perhitungan Tribolium castaneum dengan menggunakan cawan petri dan kertas saring sebagai media perhitungan seluruh rangkaian proses perhitungan dilakukan di box kaca kedap udara untuk menghindari kumbang tersebut terbang ke tempat lain. Selanjutnya ditimbang bobot dedak untuk menghitung penyusutan bobot dedak dengan level ketelitian 0,001 g.

Penelitian ini dilakukan secara eksperimental. Rancangan yang digunakan adalah rancangan acak lengkap (RAL), terdiri atas 5 perlakuan dan 4 ulangan. Data yang terkumpul dilakukan analisis dengan uji Duncan (Steel dan Torrie, 1993). Peubah yang diukur adalah kumbang yang hidup, mati, dan persentase mortalitas dan susut bobot dedak padi. 


\section{HASIL DAN PEMBAHASAN}

Hasil penelitian (Tabel 1) menunjukan bahwa investasi awal Tribolium castaneum untuk semua perlakuan sebanyak 50 ekor, dan setelah 21 hari pengamatan menunjukan adanya perbedaan $(\mathrm{P}<0,05)$ jumlah kumbang yang hidup diantara perlakuan. Artinya bahwa terdapat kematian (mortalitas) yang nyata disebabkan oleh adanya perlakuan CNSL. Semakin tinggi konsentrasi CNSL, maka semakin banyak jumlah dan prosentase Tribolium castaneum yang mati $(\mathrm{P}<0,05)$, bahkan pada dosis $40 \%$ kematian mendekati $100 \%$. Hal ini tampak jelas pada Gambar 2 yang menunjukan adanya peningkatan jumlah Tribolium castaneum yang mati seiring dengan peningkatan dosis CNSL. Sementara itu, kematian yang tinggi diikuti pula dengan semakin sedikitnya jumlah dedak padi yang menyusut/hilang $(\mathrm{P}<0,05)$.

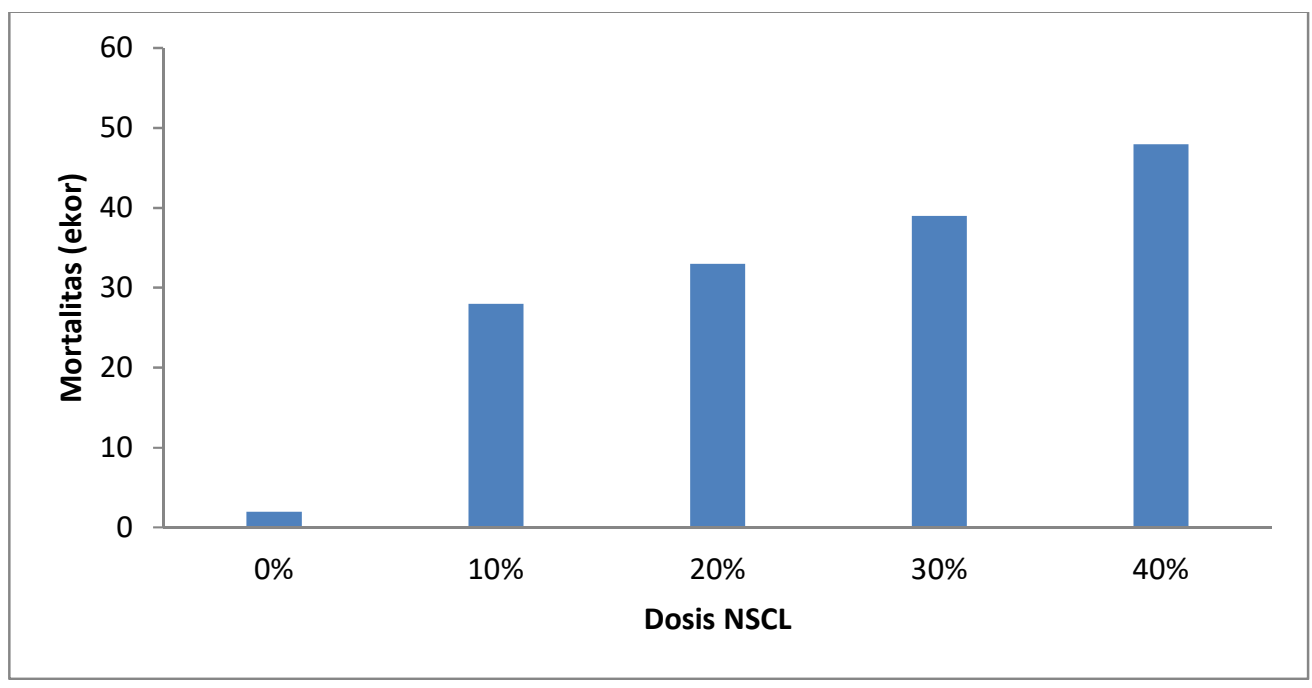

Gambar. 2. Jumlah Tribolium castaneum yang mati (mortalitas) akibat pemberian berbagai dosis NSCL

Tabel 1. Pengaruh perlakuan terhadap mortalitas Tribolium castaneum dan susut bobot dedak padi setelah 21 hari pengamatan

\begin{tabular}{lccccc}
\hline \multicolumn{1}{c}{ Peubah } & R0 & R1 & R2 & R3 & R4 \\
\hline Investasi Awal (ekor) & 50 & 50 & 50 & 50 & 50 \\
Jumlah Hidup (ekor) & $48^{\mathrm{e}}$ & $22^{\mathrm{d}}$ & $17^{\mathrm{c}}$ & $11^{\mathrm{b}}$ & $2^{\mathrm{a}}$ \\
Jumlah Mati (ekor) & $2^{\mathrm{a}}$ & $28^{\mathrm{b}}$ & $33^{\mathrm{c}}$ & $39^{\mathrm{d}}$ & $48^{\mathrm{e}}$ \\
Persentase Mortalitas (\%) & $0,04^{\mathrm{a}}$ & $0,44^{\mathrm{b}}$ & $0,66^{\mathrm{c}}$ & $0,78^{\mathrm{d}}$ & $0,96^{\mathrm{e}}$ \\
Susut Bobot Dedak Padi (g) & $0,223^{\mathrm{b}}$ & $0,204^{\mathrm{b}}$ & $0,218^{\mathrm{b}}$ & $0,178^{\mathrm{a}}$ & $0,157^{\mathrm{a}}$ \\
\hline
\end{tabular}

Keterangan : Superskrip berbeda pada baris yang sama menunjukkan berbeda nyata $(\mathrm{P}<0,05)$

Kematian yang tinggi pada Tribolium castaneum disebabkan CNSL mengandung $90 \%$ asam anakardat dan $10 \%$ kardol. Asam anakardat yang terdapat pada CNSL merupakan suatu senyawa asam yang memiliki gugus fenolik, karboksil, dan ikatan rangkap yang berpotensi sebagai gugus yang aktif dalam menghambat perkembangbiakan Tribolium castaneum. Budiati dan Ervina (2008) serta Kubo et al. 
(2003) menyatakan asam anakardat bekerja sebagai surfaktan dengan merusak dinding sel dengan menghambat enzim sulfihidril. Selanjutnya pada penelitian Asogwa et al. (2007) bahwa asam anakardat yang terkandung di dalam CNSL dapat menghambat kerja enzim prostaglandin yang berperan dalam sistim reproduksi dan fisiologis serangga.

Asam anakardat merupakan sinonim dari 2-hidroksi 6-asam pentadesilbenzoat. Secara kimiawi asam anakardat merupakan campuran dari beberapa komponen organik yang terdiri atas subtitusi asam salisilat (salicylic acid) dengan ikatan alkali yang memiliki 15 atau 17 atom karbon. Golongan alkali pada asam anakardat yang terdapat pada CNSL tersebut tersusun atas campuran molekul jenuh dan molekul tidak jenuh,

Campuran dari kedua molekul ini memiliki 15 ikatan sisi yang tidak jenuh yang bersifat letal terhadap Tribolium castaneum yang berada pada dedak padi tersebut (Warsi dan Tri, 2005). Pada penelitian lain, Iskandar (2002) menemukan bahwa CNSL sebagai bahan baku insektisida alami yang potensial untuk digunakan mengendalikan larva Ciricula trifenestrata (hama pada tanaman kayu manis dan jambu mente) dan serangga hama gudang Sitophillus sp. Hasil pengujian menunjukkan bahwa bahwa CNSL mampu mematikan larva dan imago Sitophillus sp. Hasil pengujian terhadap $C$. trifenestrata menunjukkan bahwa CNSL berpengaruh terhadap mortalitas larva dengan cara aplikasi topical, dan celup daun (Warsi dan Tri, 2004). Rumini dkk., (2004) menyatakan bahwa tingkat kematian $H$. antonii pada buah mentimun pada hari ke-3 mencapai 4 - 78\%, sedangkan menurut Iskandar dan Kardinan (1999) bahwa perlakuan CNSL $10 \%$ menimbulkan kematian larva Cricula trifenestrata.

Sementara itu, susutnya dedak padi diduga berkaitan dengan jumlah Tribolium castaneum yang hidup (Tabel 1). Sebagai mahluk hidup serangga membutuhkan makanan. Populasi yang tinggi membutuhkan makanan yang lebih banyak. Menurut Alanko (2000) komponen dedak padi yang dikonsumsi oleh Tribolium castaneum adalah pati.

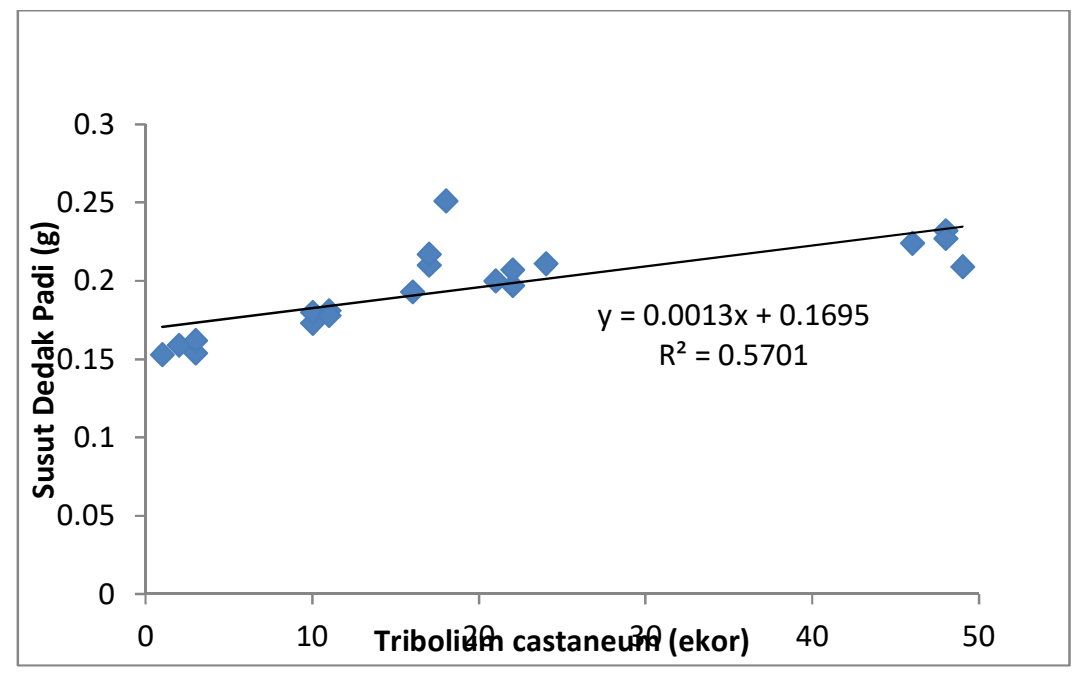

Gambar 2. Hubungan jumlah Tribolium castaneum yang hidup dengan susut dedak padi

Hubungan antara jumlah hidup Tribolium castaneum dengan susut dedak padi dinyatakan dengan nilai korelasi (r) sebesar 0,76. Angka tersebut menunjukan hubungan yang erat antara jumlah hidup dengan susut dedak padi (Sugiyono, 2007). 
Artinya semakin banyak Tribolium castaneum akan diikuti dengan banyaknya dedak padi yang dikonsumsi membentuk

\section{KESIMPULAN}

Penggunaan $\quad 40 \% \quad$ CNSL menyebabkan mortalitas yang maksimal pada Tribolium castaneum. Hubungan antara jumlah hidup Tribolium castaneum dengan susut dedak padi membentuk persamaan regresi $\mathrm{Y}=0,0013 \mathrm{X}+0,1695$ dan memiliki hubungan yang erat dengan nilai korelasi $\mathrm{r}$ $=0,76$.

\section{DAFTAR PUSTAKA}

Alanko, B.D., Richard, B., and Sprout, T.N. 2000. Warehouse Pest Mamangement in Tropical Areas. Leigh Jhonson. Inc. Perth.

Asogwa, E.U., Mokwunye, I.U., Yahaya, L.E. and A.A. Ajao, A.A. 2007. Evaluation of cashew nut shell liquid as a potential natural insecticide against termites. Research Journal of Applied Sciences 2(9) : 939 - 942.

Budiarti dan M. Ervina. 2008. Hubungan antara struktur asam anakardat dan aktivitas antibakteri terhadap Staphylococcus aureus. Jurnal Obat Bahan Alami 7 (1) : 108 -114.

Cypra, B.A. 2001. In population Dynamic. It's dogma eta dogma world. Siam News Minnesota. Journal of Grain Products. 36 (9): 341-359

Freeman. J. 1995. Crop Preservative Management. AWSD Press. USA

Himejima, M, and Kubo, J. 1991. Antibacterial Agent from the Cashew Anacardiurn occidentale L (Anacardiaceae) Nut Shell Oil, J. Agriculture Food Chemistry, 9 : 418-421. persamaan regresi $\mathrm{Y}=0,0013 \mathrm{X}+0,1695$ dengan nilai $\mathrm{R}^{2}=0,5701$ (Gambar 1).

Iskandar, M. dan Agus Kardinan, 1999. Potensi insektisida nabati CNSL terhadap larva Cricula trifenestrata dan Doleschalia polibete pada tanaman industri. Prosiding Seminar Nasional PEI. Peranan Entomologi dalam Pengendalian Hama Ramah Lingkungan dan Ekonomis. hal. 282 $-292$.

Iskandar, M. 2002. Prospek CNSL (Cashew Nut Shell Liquid) sebagai bahan baku industri insektisida nabati. Hasilhasil Penelitian Tanaman Rempah dan Obat Mendukung Otonomi Daerah. Perkembangan Teknologi Tanaman Rempah dan Obat. 16 (2) : $35-42$.

Kubo, I., Ochi M., Vieira P.C. and Komatsu S. 1993, Antitumor agents from the cashew (Anacardium occidentale) apple juice. Journal Agric. Food Chem. 41 : $1012-1015$.

Marthin, K. 2001. Tribolium in Cereal Grain. Institute fur Zoogie Staudtrasce, Erlangen, Germany

Murty, B.G.K. and Sivasamban, 1984. Recent trend in CNSL utilization cashew. E.V. Bhsakara Rao and H.M. Khan (Eds) Indians Society for Plantation Crops Karala, India. pp. $82-92$.

Rumini, W., W.R. Atmaja, S. Suriati dan M. Iskandar, 2004. Pengaruh cashew nut shell liquid (CNSL) terhadap Helopeltis antonii Sign. pada inang alternatif. Seminar Nasional IV Entomologi dalam Perubahan Lingkungan dan Sosial Bogor, 5 Oktober 2004. 6 hal 
Sugiyono. 2007. Metode Penelitian pedidikan pendekatan kuantitatif, kualitatif, dan R\&D. Bandung: ALFABETA

Steel, R.G.D. dan J.H. Torrie. 1993. Prinsip dan Prosedur Statistika. PT. Gramedia Pustaka Utama.
Tyman, J.H.P. 1975. Quantitative determination of the olefinic composision of the component phenols in cashew nut shell liquid. J. Chrom 3 :.277-284.

Warsi, R.A. dan Tri, E.W. 2004. Pengaruh chasew nut shell liquid (CNSL) terhadap mortalitas Helopeltis antonii Sign pada bibit jambu mete. Bu. Litro 17 (2) : 66-71 